\title{
Diagnostic importance of the concentration of milk amyloid A in quarter milk samples from dairy cows with mastitis
}

\author{
Milan Vasil', Juraj Elečko, Zuzana Farkašová, František Zigo \\ Institute of Animal Husbandry, Department of Nutrition, Dietetics and Animal Breeding, \\ University of Veterinary Medicine and Pharmacy in Košice, Slovak Republic
}

Received August 2, 2011

Accepted January 18, 2012

\begin{abstract}
Acute phase proteins have been used as biomarkers of inflammation. Their concentrations increase in milk from cows with latent and subclinical mastitis. The aim of our study was to evaluate milk amyloid A (MAA) as indicator of udder inflammation. We used 24 dairy cows from a herd with 120 Slovak Pied cattle. In addition to bacteriological examination, the following indicators were determined in all quarter milk samples. On the basis of results of clinical examination, Californian mastitis test (CMT), and number of Somatic cell count (SCC), four groups of quarter milk samples were formed. The levels of MAA in both subgroups of Group 1 (healthy cows), divided by the number of SCC - IA $(n=10)$, IB $(n=15)$, determined at repeated samplings, differed significantly from the initial levels $(P<0.01)$. Highly significant correlation $\left(\mathrm{R}^{2}=0.272\right)$, was detected between SCC, and MAA in Group $2(\mathrm{n}=27)$ at individual collections $(P<0.01)$, while in the Group $3(\mathrm{n}=25)$ the level of both indicators decreased by the end of the experiment despite higher initial concentrations $(P<0.01)$. No significant differences in MAA were observed between individual collections in Group $4(n=6)$. No positive correlation $\left(\mathrm{R}^{2}=0.525\right)$ was detected between SCC and MAA in this group. The obtained results allowed us to conclude that MAA in milk can act as a marker of inflammation of the udder only in the initial, asymptomatic stages of dairy cow mastitis. The experiment was one of first studies with MAA in Slovak Pied cattle.
\end{abstract}

Acute phase protein, Staphylococcus spp., dairy cattle

Bovine mastitis is the most costly disease in the dairy industry and can be caused by at least 135 different agents, mostly bacteria (Yancey 1999). The majority of infections are caused by the contagious pathogens Staphylococcus aureus, Streptococcus agalactiae, Streptococcus dysgalactiae, and by the environmental pathogens Streptococcus uberis and Escherichia coli.

The golden standard for measuring inflammation of the mammary gland is cytological examination, somatic cell count (SCC) in milk, and other methods (Hamann 2002). The somatic cell count has become a widely used index of mastitis and the California Mastitis Test (CMT) is a method of estimating SCC with potential on-farm utility (O'Mahony et al. 2006).

Whole cattle herd screening for serum amyloid A can be a useful value to the veterinarian in identifying cows with inflammatory diseases (Karreman et al. 2000). The stages of disease can be better evaluated by monitoring more than one acute phase protein. Chronic as well as acute inflammatory processes should be evaluated by acute phase protein profiling (Eckersall 2004).

The diagnosis of mastitis is based predominantly on clinical examination, measurements of SCC and the cultivation of pathogens from milk, but there is demand for objective and rapidly assessable markers of udder health. The acute phase proteins have recently been suggested as such indicators of inflammation in the mammary gland (Nielsen et al. 2004). Further investigations showed an extra hepatic synthesis of specific isoform of amyloid A from mammary epithelial cells, the so-called milk amyloid A (MAA) (McDonald et al. 2001).

Address for correspondence:

Doc. MVDr. Milan Vasil', CSc.

Institute of Animal Husbandry

University of Veterinary Medicine and Pharmacy

Phone: +421 552982630

Komenského 73, 04181 Košice, Slovak Republic

http://actavet.vfu.cz/ 
As the MAA occurs in milk early in the inflammatory process and its presence is apparently specific to local and not systemic inflammation, it may be a useful indicator of infection.

The aim of our study was to compare the concentrations of MAA in quarter milk samples from healthy cows and in milk samples from cows with staphylococcal infection with SCC and CMT cellular indices of mammary inflammation.

\section{Materials and Methods}

Animals

The study was carried out on 120 dairy cows (Slovak Pied cattle) on the Trhovište farm in Eastern Slovakia. The cows were kept in free box housing system and milked in DeLaval parlour, tandem $2 \times 4$ (Tumba, Sweden). Based on the results of two examinations, 24 cows in the $3^{\text {rd }} 4^{\text {th }}$ lactation were used in the study. Clinical examination of the mammary gland was performed by visual inspection and palpation using standard physical methods of examination. To detect sub-clinical mastitis, the California mastitis test and somatic cell count (STN EN ISI) were performed. Milk samples from all 24 cows were examined microbiologically with focus on isolation and identification of pathogens such as Staphylococcus spp. and detection of milk amyloid A.

According to clinical examination of the udder, results of CMT and SCC (Jackson and Cockcroft 2002), the animals were divided into 4 groups: Group 1 with subgroup 1A that included cows without clinical changes in the mammary gland, with negative CMT and with $\mathrm{SCC}<0.15 .10^{6} / \mathrm{ml}(\mathrm{n}=10$ quarters in 4 dairy cows), subgroup 1B included cows without clinical changes on the mammary gland, with negative CMT and with SCC in the range of $0.15-0.20 .10^{6} / \mathrm{ml}(\mathrm{n}=15$ quarters in 4 dairy cows). Group 2 included cows without clinical changes in the mammary gland, with trace CMT and with SCC in the range of $\left.0.20-0.30 .10^{6} / \mathrm{ml}\right)(\mathrm{n}=27$ quarters in 7 dairy cows). Group 3 included cows without clinical changes in the mammary gland, with trace CMT and with SCC in the range of $0.30-0.40 .10^{6} / \mathrm{ml} ; 72 \%$ samples with less than 5 colonies of Staphylococcus spp. $(\mathrm{n}=25$ quarters in 7 dairy cows). Group 4 included cows with clinical changes on the mammary gland, with trace CMT and with SCC in the range of $0.40-0.60 .10^{6} / \mathrm{ml}$ and with presence of clots and flakes in milk and abnormal milk colour; all quarters were infected with Staphylococcus spp. ( $\mathrm{n}=6$ quarters in 2 dairy cows).

Methods of udder examination and analysis of milk

Clinical changes in udder were diagnosed by the presence of observable signs of inflammation in the infected quarter, such as swelling, heat, pain or redness, and by the presence of clots and flakes in the milk, or by its abnormal colour or consistency.

Californian mastitis test was performed using equal volumes of milk and alkyl-aryl-sulphonate and was evaluated as: 1) negative (-), not infected, healthy quarter, no thickening of the mixture; 2 ) trace ( \pm ), possible infection, slight thickening of the mixture; 3 ) weak positive (+), infected, distinct thickening of the mixture but no tendency to form a gel.

Milk samples were collected at exactly set time intervals: Zero, 12, 24, 36, 84, and $180 \mathrm{~h}$. Intervals of sample collections respected milking time, and specifications for our experiment. Milk samples were collected before milking.

Somatic cell count (SCC)

Quarter milk samples were collected by hand-stripping after CMT and sample collecting for microbiological examination and MAA detection. Milk was collected from every quarter into a $25 \mathrm{ml}$ tube with stabilized reagent $\left(1 \mathrm{mg} / 1 \mathrm{ml}\right.$ kalium dichromate). After shuffling, samples were transported at the temperature from $1{ }^{\circ} \mathrm{C}$ to $10^{\circ} \mathrm{C}$ to the laboratory, and examined within the next $24 \mathrm{~h}$. Somatic cell count in quarter milk samples was detected according to STN EN IS/ 13 366-3: 2000 by Fossomatic 5000, (FOSS Electric, Hølstebro, Denmark).

Quarter milk samples for microbiological examination were collected from each observed cow as follows: after drawing and evaluation of the first 6 squirts of milk, the teat ends were disinfected with cotton wool dipped in $70 \%$ etyl-alcohol. Milk was then collected aseptically from teats directly into sterile $10 \mathrm{ml}$ tubes, holding the tubes at an angle of approximately $45^{\circ}$. The samples were kept at $4-8{ }^{\circ} \mathrm{C}$ during transportation to the laboratory.

Staphylococcus spp. detection and identification

Milk samples $(0.05 \mathrm{ml})$ were inoculated onto blood agar (Oxoid, UK) and cultivated at $36^{\circ} \mathrm{C}$ for $24 \mathrm{~h}$. Based on the colony morphology, bacteria Staphylococcus spp. were selected for the tube coagulase test (Staphylo PK, ImunaPharm, Šarišské Michalany, Slovakia). Suspect colonies were isolated again on blood agar, cultivated at $36{ }^{\circ} \mathrm{C}$ for $24 \mathrm{~h}$ and identified biochemically using the STAPHYtest and identification software TNW Pro 7.5 (PlivaLachema, Brno, Czech Republic). In case of doubtful results the respective strains were sent to the Czech Strain Collection of Microorganisms in Brno for more accurate identification using specific biochemical tests or molecular methods. Identification of bacteria of Staphylococcus spp. was made according to the scheme described in Bergey's manual of Systematic Bacteriology (2009).

Milk amyloid A (MAA)

Concentrations of MAA were measured in 83 quarter milk samples. Samples of milk for detection of MAA were collected from every quarter into sterile tubes after collection for microbiological examination. Milk samples were 
frozen at $-20{ }^{\circ} \mathrm{C}$. The results of these separate milk samples were categorized according to the same criteria as those used for cows. Concentrations of MAA were determined by Enzyme-linked Immunosorbent Assay (ELISA) using commercial diagnostic kits (Tridelta Development, Ireland). An automatic Microplate Reader MRX (Dynex Technologies, USA) was used to read the absorbancies and to calculate the final MAA concentrations.

Statistics

Evaluation of results was performed by assessment of means (x) and standard deviations (sd) for each evaluated variable. The significance of differences in means between the variables measured in milk from individual groups was evaluated by One Way Analysis of Variance (ANOVA) and Dunnett's Multiple Comparison Test. Relationship between the concentrations of MAA and SCC in separate milk samples were calculated by Pearson's $\left(\mathrm{R}^{2}\right)$ correlation coefficient, including significance of correlations. Significant differences and significant correlations were presented as $P<0.05, P<0.01, P<0.001$. Statistical analyses were performed using software GraphPad Prism 5 .

\section{Results}

The results obtained in the evaluated groups of cows, expressed as mean values, standard deviations, and significance of differences between means, and correlations are presented in Tables 1-3. The first group of cows was divided to two subgroups $1 \mathrm{~A}(\mathrm{n}=15)$ and $1 \mathrm{~B}(\mathrm{n}=10)$ according to SCC $\left(<0.15 \times 10^{6} / \mathrm{ml} ; 0.15-0.2 \times 10^{6} / \mathrm{ml}\right)$. All quarter milk samples from these cows were considered healthy (Table 1). The concentration of MAA in these subgroups changed in dependence on the time of sample collection. Significant differences in concentrations of MAA $\left(P<0.001, \mathrm{R}^{2}=0.1934\right)$ were observed between repeated collections and the initial concentration in both subgroups, particularly in Group $1 \mathrm{~B}$, even though the numbers of SCC were relatively equal.

Table 1. Concentrations of milk amyloid A in cows producing healthy milk (Group 1)

\begin{tabular}{lrrrrrc}
\hline Sampling & \multicolumn{1}{c}{0} & 12 & 24 & 36 & 84 & 180 \\
\hline $1 \mathrm{~A}$ & $5.5^{\mathrm{a}, \mathrm{b}, \mathrm{c}} \pm 1.52^{*}$ & $3.83^{\mathrm{a}} \pm 0.92$ & $4.94 \pm 0.50$ & $8.66^{\mathrm{b}} \pm 0.48$ & $3.49^{\mathrm{a}} \pm 3.22$ & $2.65^{\mathrm{c}} \pm 1.83$ \\
$1 \mathrm{~B}$ & $27.12^{\mathrm{c}, \mathrm{b}} \pm 31.11$ & $6.12^{\mathrm{c}} \pm 4.36$ & $5.89^{\mathrm{c}} \pm 1.28$ & $10.80^{\mathrm{b}} \pm 2.29$ & $5.84^{\mathrm{c}} \pm 2.87$ & $3.52^{\mathrm{c}} \pm 1.40$ \\
\hline
\end{tabular}

*the results are presented as $\mathrm{x} \pm \mathrm{sd}, \mathrm{x}$ - means, $\mathrm{sd}$ - standard deviation, significant differences between zero hour and other hours are marked by superscripts, ${ }^{\mathrm{a}} P<0.05,{ }^{\mathrm{b}} P<0.01,{ }^{\mathrm{c}} P<0.001$, One-Way ANOVA, Dunnett's multiple comparison test, Group 1A $(\mathrm{n}=10)$ with somatic cell count $0.15-0.2 \times 10^{6} / \mathrm{ml}$, Group $1 \mathrm{~B}(\mathrm{n}=15)$ with $\mathrm{SCC}<0.15 \times 10^{6} / \mathrm{ml}$

At the beginning of the experiment the quarter milk samples collected from cows of Group 2 showed negative CMT, low SCC $\left(0.2-0.3 \times 10^{6} / \mathrm{ml}\right)$, and absence of clinical signs of mastitis (Table 2). An increase in SCC followed by its decrease, positive CMT, but no clinical signs of udder inflammation were observed during the experiment. We observed highly significant positive correlation between the concentrations of MAA and SCC at individual collections $\left(\mathrm{n}=27, \mathrm{R}^{2}=0.361, P<0.001\right)$.

Table 2. Correlation between concentrations of milk amyloid A and somatic cell count in milk of cows from Groups 2 and 3

\begin{tabular}{lcccccc}
\hline $2^{\text {nd }}$ & 0 & 12 & 24 & 36 & 84 & 180 \\
\hline SCC & $0.20^{\mathrm{b}} \pm 0.07$ & $2.26^{\mathrm{c}} \pm 2.30$ & $0.97^{\mathrm{a}} \pm 1.38$ & $2.55^{\mathrm{a}} \pm 2.07$ & $1.42 \pm 1.62$ & $1.01 \pm 1.09$ \\
MAA & $19.75^{\mathrm{b}} \pm 28.2$ & $21.13^{\mathrm{c}} \pm 34.2$ & $16.21^{\mathrm{a}} \pm 22.2$ & $27.67^{\mathrm{a}} \pm 33.99$ & $24.53 \pm 43.32$ & $12.45 \pm 22.77$ \\
\hline $3^{\text {nd }}$ & 0 & 12 & 24 & 36 & 84 & 180 \\
\hline SCC & $1.56^{\mathrm{b}} \pm 1.73$ & $3.13 \pm 2.06$ & $2.56^{\mathrm{c}} \pm 2.20$ & $2.88^{\mathrm{b}} \pm 2.15$ & $2.35^{\mathrm{b}} \pm 1.79$ & $1.83^{\mathrm{a}} \pm 1.93$ \\
MAA & $34.65^{\mathrm{b}} \pm 38.87$ & $45.02 \pm 49.1$ & $32.08^{\mathrm{c}} \pm 40.9$ & $39.27^{\mathrm{b}} \pm 40.2$ & $25.49^{\mathrm{b}} \pm 34.6$ & $17.33^{\mathrm{a}} \pm 22.9$ \\
\hline
\end{tabular}

Correlations between the values determined at individual sample collections, ${ }^{\mathrm{a}} P<0.05,{ }^{\mathrm{b}} P<0.01,{ }^{\mathrm{c}} P<0.001$; One-way ANOVA; $\mathrm{x}$ - means; sd - standard deviation, MAA - milk amyloid A, SCC - somatic cell count (Group 2 ( $\mathrm{n}=27), 0.20-0.30 .10^{6} / \mathrm{ml}$; Group $3(\mathrm{n}=25)$ 0.30-0.40.10\% $\left./ \mathrm{ml}\right), \mathrm{SCC}=10^{6} / \mathrm{ml} ; \mathrm{MAA}=\mathrm{ng} / \mathrm{ml}$ 
Table 3. Concentrations of milk amyloid A and somatic cell count in milk from Group 4 at individual collections

\begin{tabular}{lrrrrrr}
\hline & \multicolumn{1}{c}{0} & 12 & \multicolumn{1}{c}{24} & \multicolumn{1}{c}{36} & 84 & 180 \\
\hline SCC & $0.33 \pm 0.43$ & $1.16 \pm 0.82$ & $0.43 \pm 0.26$ & $0.84 \pm 0.52$ & $2.31 \pm 2.68$ & $0.65 \pm 0.37$ \\
MAA & $10.12 \pm 5.87$ & $8.35 \pm 4.62$ & $5.97 \pm 1.36$ & $10.62 \pm 1.80$ & $6.08 \pm 4.57$ & $2.02 \pm 0.91$ \\
\hline
\end{tabular}

$\mathrm{x}$ - means; sd - standard deviation; MAA $=\mathrm{ng} / \mathrm{ml}$; Group $4(\mathrm{n}=6)-\mathrm{SCC}=0.40-0.60 .10^{6} / \mathrm{ml}$, with presence of clots and flakes in the milk and abnormal colour of milk; and infected with Staphylococcus spp.; MAA- milk amyloid A, SCC- somatic cell count

Milk samples from Group 3 (Table 2), taken at the beginning of the experiment showed higher SCC $\left(0.3-0.4 \times 10^{6} / \mathrm{ml}\right)$, changes in consistency and colour of milk by CMT. We determined 18 positive findings (from 25) in Group 3, where the isolations of Staphylococcus spp. (S. xylosus, S. lentus, S. warneri, S. chromogenes) were under 5 colonies. The other milk samples were negative. There was a significant correlation between MAA and SCC at individual collections $\left(\mathrm{n}=25, \mathrm{R}^{2}=0.454, P<0.001\right)$. However, after higher values at the beginning of observation (after the primary increase), the concentrations were constant at the end of the experiment. The values of MAA and SCC in milk decreased at the last collections compared to the initial levels.

The six milk samples in Group 4 were collected from cows with clinical (sub-clinical) staphylococcal mastitis (Table 3). The initial results of microbiological examinations indicated staphylococcal infection with clinical signs of mastitis in Group 4 (S. xylosus, $S$. lentus, $S$. hyicus). In the samples, different numbers of SCC $\left(0.4-0.6 \times 10^{6} / \mathrm{ml}\right)$, and different positive CMT were measured during the experiment. We did not detect significant differences $(P>0.05)$ between the concentrations of MAA at individual milk collections but all the other indicators fluctuated. No positive correlation $\left(\mathrm{R}^{2}=0.525\right)$ was observed between SCC and MAA.

\section{Discussion}

As alternative biomarkers of mastitis, acute phase proteins (APPs) may increase in concentration in the absence of macroscopic changes in milk, or they may precede the onset of clinical signs (Safi et al. 2009).

Petersen et al. (2005) reported that the MAA concentrations were higher in udder quarters with mastitis compared to healthy quarters. Gerardi et al. (2009) reported that MAA concentrations significantly differed between cows with subclinical and clinical mastitis compared to healthy cows. In our experiment we determined higher concentrations of MAA in milk samples with staphylococcal infection compared to healthy milk. The concentrations of MAA in group of healthy cows varied in dependence on the time of sample collection. We found significant differences in MAA concentrations at repeated collections compared to the initial value. This was observed in both subgroups $1 \mathrm{~A}$ and $1 \mathrm{~B}$.

O'Mahony et al. (2004) reported significant correlation between MAA concentrations and both the SCC and CMT. In the second group we observed significant correlation $\left(\mathrm{R}^{2}=0.361, P<0.001\right)$ between the concentrations of MAA and SCC. The highest mean concentration was measured $36 \mathrm{~h}$ after the start of the experiment; at the beginning of the experiment CMT was negative and SCC was low, corresponding to healthy milk.

The concentration of MAA in separate quarter milk samples as well as in composite milk samples increased significantly with increasing positivity of CMT (Kováč et al. 2009). We found significantly positive correlation $\left(\mathrm{R}^{2}=0.361, P<0.001\right)$ between MAA and SCC; the values of MAA and SCC showed similar decreasing or increasing tendencies. 
According to Berry et al. (2005), MAA concentrations $800 \mathrm{ng} / \mathrm{ml}$, and SCC $>200000$ cells $/ \mathrm{ml}$ are indicative of an inflammatory response. In contrast, Nazifi et al. (2008) reported $6.96 \mu \mathrm{g} / \mathrm{ml}$ mean MAA concentration for clinically healthy cows, and $54.53 \mu \mathrm{g} / \mathrm{ml}$ for cows with sub-clinical mastitis. Eckersall et al. (2006) reported that the mean concentration of M-SAA3 increased from the pre-treatment level of $<0.3 \mu \mathrm{g} / \mathrm{ml}$ to a mean concentration of $5.6 \pm 12 \mu \mathrm{g} / \mathrm{ml}$ at the first sampling time post treatment $(15 \mathrm{~h})$, and to a peak of $20.9 \pm 11.9 \mu \mathrm{g} / \mathrm{ml}$ by day 2 . The mean concentrations of MAA in samples of healthy milk in our study ranged from 2.65 to $27.12 \mathrm{ng} / \mathrm{ml}$. In contrast, the highest measured concentration (186.31) was detected in samples with dubious CMT and low SCC $\left(0.88 \times 10^{6} / \mathrm{ml}\right)$. The highest concentration of MAA with markedly positive CMT $(+)$ and high number of SCC $\left(6.0 \times 10^{6} / \mathrm{ml}\right)$ was $163.99 \mathrm{ng} / \mathrm{ml}$. These contradictory data indicate that further studies are necessary to extend our knowledge about the levels of MAA under such conditions.

Kováč et al. $(2009,2011)$ found the highest mean MAA concentration in composite milk samples from cows with clinical changes in mammary gland and cows without clinical signs of mastitis, but with markedly positive CMT. The concentrations of Hp and SAA were higher in the serum of cows with clinical mastitis and increased with the increasing CMT score. Haghkhah et al. (2010) found significant differences $(P<0.05)$ in concentrations of milk Hp, MAA and somatic cell count between clinically healthy cattle and cows with clinical and sub-clinical mastitis. We found the highest concentrations of MAA in milk samples from cows without clinical signs of mastitis; but they were also high in milk from cows with clinical mastitis. No significant correlation was found between the MAA and SCC in samples from animals with clinical mastitis whereas Kováč et al. (2009) reported high positive correlation between these values.

In our experiment we determined lower concentrations of MAA in healthy bovine milk samples compared to MAA in milk from cows with clinical mastitis. However, these values differed significantly during the experiment which may be related to changes in SCC. We can conclude that the milk amyloid A as marker of udder inflammation responds very sensitively to little changes in milk at the start of infection. It was also evident that in milk samples from animals with clinical mastitis with $\mathrm{SCC}>0.5 \times 10^{6} / \mathrm{ml}$, and milk with positive CMT $(+)$, the concentrations of MAA did not correlate with other determined indicators commonly used to detect mastitis. This indicates that the MAA concentration in milk cannot be considered a reliable indicator for detection of clinical mastitis.

\section{Acknowledgements}

This work was supported by project APVV-0629-07 and by project APVV-0679-10.

\section{References}

Bergey's manual of Systematic Bacteriology 2009: Vol. III, second edition 2009

Berry EA, Hillerton JE, Torgerson P 2005: Use of acute phase proteins in bovine milk. $5^{\text {th }}$ International Colloquium on Animal Acute Phase Proteins - Dublin - March 2005: 28

Eckersall PD 2004: The time is right for acute phase protein assays. Vet J 168: 3-5

Eckersall PD, Young FJ, Nolan AM, Knight CH, McComb C, Waterston MM, Hogarth CJ, Scott EM, Fitzpatrick JL 2006. Acute phase proteins in bovine milk in an experimental model of Staphylococcus aureus subclinical mastitis. J Dairy Sci 89: 1488-1501

Gerardi G, Bernardini D, Elia CA, Ferrari V, Iob L, Segato S 2009: Use of serum amyloid A and milk amyloid A in the diagnosis of subclinical mastitis in dairy cows. J Dairy Res 76: 411-417

Haghkhah M, Nazifi S, Jahromi A 2010: Evaluation of milk haptoglobin and amyloid A in high producing dairy cattle with clinical and subclinical mastitis in Shiraz. Comparative Clinical Pathology 19: 547-552

Hamann J 2002: Milk quality and udder health in relation to modern technique. Proceedings of the XXII World Buiatrics Congress, Hannover, Germany, August 18-23: 334-345

Karreman HJ, Wentink GH, Wensing T 2000: Using serum amyloid A to screen dairy cows for subclinical inflammation. Vet Q 22: 175-178 
Jackson P, Cockcroft P 2002: Clinical examination of farm animals. Blackwell Science Ltd., Oxford, UK: 154-166

Kováč G, Tóthová Cs, Nagy O, Seidel H 2009: Milk Amyloid A and selected serum proteins in the diagnosis of mastitis in dairy cows. Folia Veterinaria Proccedings: X. Middle -European Bujatrics Congress, UVL Košice: 179-183

Kováč G, Tóthová Cs, Nagy O, Seidel H 2011: Milk amyloid a and selected serum proteins in cows suffering from mastitis. Acta Vet Brno 80: 3-9

McDonald TL, Larson MA, Mack DR, Weber A 2001: Elevated extrahepatic expression and secretion of mammary-associated serum amyloid A3 (M-SAA3) into colostrums. Vet Immunol Immunopathol 83: 203-211

Nazifi SI, Khoshvaghti A, Gheisari HR 2008: Evaluation of serum and milk amyloid A in some inflammatory diseases of cattle. Iran J Vet Res 24: 222-226

Nielsen BH, Jacobsen S, Andersen PH, Niewold TA, Heegaard PMH 2004: Acute phase protein concentrations in serum and milk from healthy cows, cows with clinical mastitis and cows with extramammary inflammatory conditions. Vet Rec 154: 361-365

O'Mahony MC, Healy AM, Harte D, Torgerson PR, Walshe KG, Doherty ML 2004: Milk amyloid A in the diagnosis of bovine subclinical mastitis. Available on: www.agresearchforum.com./ ARF 2004 proceedings: 39, available and accessed from 2002

O'Mahony MC, Healy AM, Harte D, Walshe KG, Torgerson PR, Doherty ML 2006: Milk amyloid A: Correlation with cellular indices of mammary inflammation in cows with normal and raised serum amyloid A. Res Vet Sci 80: $155-161$

Petersen HH, Gardner IA, Rossitto P, Larsen HD, Heegaard PMH 2005: Accuracy of milk amyloid A (MAA) concentration and somatic cell count for diagnosing bovine mastitis. $5^{\text {th }}$ International Colloquium on Animal Acute Phase proteins, Dublin: 43-44

Safi S, Khoshvaghti A, Jafarzadeh SR, Bolourchi M, Nowrouzian I 2009: Acute phase proteins in the diagnosis of bovine subclinical mastitis. Vet Clin Pathol Abstr 3: 471-476

Yancey R J 1999: Vaccines and diagnostic methods for bovine mastitis. Fact and fiction. Adv Vet Med 41: 257-273 